$1-1-1928$

\title{
The Effect of Height of Head on Young Apple Tree Growth and Yield
}

\author{
H. L. Crane
}

Follow this and additional works at: https://researchrepository.wvu.edu/ wv_agricultural_and_forestry_experiment_station_bulletins

\section{Digital Commons Citation}

Crane, H. L., "The Effect of Height of Head on Young Apple Tree Growth and Yield" (1928). West Virginia Agricultural and Forestry Experiment Station Bulletins. 214.

https://researchrepository.wvu.edu/wv_agricultural_and_forestry_experiment_station_bulletins/214 @ WVU. It has been accepted for inclusion in West Virginia Agricultural and Forestry Experiment Station Bulletins by an authorized administrator of The Research Repository @ WVU. For more information, please contact ian.harmon@mail.wvu.edu. 


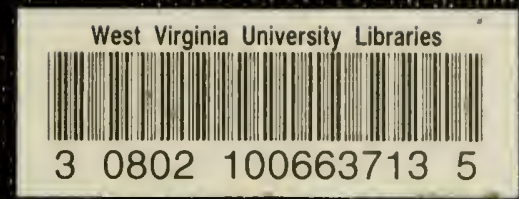


EVANSDALE LIBRARY

WEST VRGINIA UNMERSITY 
Restricted

Circulation Only

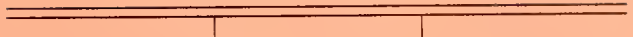





\section{AGRICULTURAL EXPERIMENT STATION STAFF}

FRANK BUTLER TROTTER, A. M., LL. D.

President of the Univ

N. J. GIDDINGS, Ph. D.

Acting Dean and Di

WALTER C. SCHNOPP, B. S. Agr.

Agricultural I

JOHN C. JOHNSTON Chief

\section{AGRONOMY AND GENETICS}

R. J. Garber, Ph. D. Agronomist and Geneticist

E. P. Deatrick, Ph. D.

Associate Agronomist (Soils)

T. E. Odland, Ph. D.

Associate Agronomist

T. C. McIlvaine, Ph. D. $\dot{T}$

Assistant Agronomist (Soils)

D. R. Dodd, M. S.

M. M. Hoover, M. S.

Assistant Agronomist

H. K. Rowley, M. S. Agr.*:

Junior Agronomist Seed Analyst

\section{ANIMAL HUSBANDRY}

E. A. Livesay, M. S.

Animal Husbandman

Chas. V. Wilson, M. S.

Assistant Animal Husbandman

.I. H. Longwell, M. A.

Assistant Animal Husbandman

J. H. Rietz, D. V. M.

Associate Veterinarian

R. H. Tuckwiller, B. S. Agr.*

Assistant Animal Husbandman

\section{CHEMISTRY}

R. B. Dustman, Ph. D.

Associate Chemist

Chas. F. Wealkley, Jr., B. A.

Assistant Chemist

L. P. Fansen, Ph. D.

T. B. Leith, B. A.**

Assistant Chemist

Assistant Chemist

Leland Shriver

Assistant in Chemistry

DAIRY HUSBANDRY

E. L. Anthony, M. S. Agr.

H. O. Henderson, M. S. Agr.

Dairy Husbandman Associate Dairy Husbandman

G. Malcolm Trout, M. S.

Assistant Dairy Husbandman

\section{ENTOMOLOGY}

L. M. Peair's, Ph. D.

Entomologist

W. E. Rumsey, B. S.** State Entomologist

L. E. Dills, M. S.**

Assistant in Entomology

\section{FARM ECONOMICS}

A. J. Dadisman, Ph. D.

Paul A. Eke, Ph. D.

Assistant Farm Econ

F. D. Cornell, Jr., M. S.

Junior Farm Mechar iil

W. W. Armentrout, M. S.

Junior Farm Econ

\section{HOME ECONOMICS}

Rachel H. Colwell, A. M.

Hazel C. Cameron, M. S.

Home Econ is

Research Specialist in

Nell Nesbitt, A. M.

Research Specialist in Home

HORTICULTURE

H. E. Knowlton, Ph. D.

Associate Forticull

H. L. Crane, M. S. Agr.

Associal.e Horlicul!

K. C. Westover, M. S. Agr. Assistant Horlicul

Ernest Angelo, Mr. S. Agr.

Junior Horlicul

L. F. Sutton, B. S. Agr.* Assistant Horlicult

H. P. Sevy, M. S. Agr. Assistant in Horlicull

M. B. Hoffman, M. S. Assistant in Forticu

\section{PLANT PATHOLOGY}

N. J. Giddings, $\mathrm{Ph}$. D.

Anthony Berg, M. S.

Plant. Pathitol is Associate Plant: Pathol

L. H. Leonian, Ph. D.

Associate Jlant Pathol

E. C. Sherwood, M. S.

Assistant Plant: Palthol

POULTRY HUSBANDRY

Horace Atwood, M. S. Agr. Poultry Hiusluane

E. T. Wightman, M. S. Agr. Junior Poultry H.usbancm

RURAL SOCIOLOGY

T. L. Harris, Ph. D.

Rura, Sociol

\section{ZOOLOGY}

F. E. Chidester, Ph. D.

Zool

*In cooperation with the U. S. Department of Agriculture, Washington, D. $\rightarrow$ In charge of the Lakin Sub-station, Lakin, W. Va.

**In cooperation with the State Department of Agriculture, Charleston, W. V: IIn charge of the Reymann Memorial Farms, Wardensville, W. Va. 


\section{The Effect of Height of Head on Young Apple Tree Growth and Yield*}

\section{(A Preliminary Report)}

An experiment to determine the effect that the height of head of oung apple trees has on growth and yield was started in the spring of 16. For the purpose of this work, two varieties, Rome and Stayman, hich are quite distinct in nature and type of growth, were used. Onear-old trees, carefully selected for uniformity of size and vigor, were anted. These trees were of the nursery grade, five to seven feet, al for the most part were approximately seven feet high. The root stems of the individual trees were pruned as nearly alike as possible fore planting, removing mainly the broken roots and cutting off the ugh, irregular ends.

Five pruning treatments, or heights of heads, were made of each the two rarieties. They were: (1) tops eut back to 1 -foot trunk; tops cut back to 2-foot trunk; (3) tops cut back to 3 -foot trunk; tops cut back to 4 -foot trunk; and (5) tops ent back to 5 -foot min.

In every case the length of the trunk left after pruning was rasured from the point at which the tree was budded, to the apex. I an effort to obtain a length of tree trunk of $1,2,3,4$, or 5 feet, as the se might be, the trees were set so that the point at which they were idlerl was just at the surface of the soil.

The experimental work was conducted on a single row of trees ough an orchard on the Horticultural farm at Morgantown. The hard was planted with rows sixteen feet wide, and the trees thirteen $t$ apart in the rows. Two trees of Rome and four of Stayman were ud for each height of head or pruning treatment, making thirty tiss in all. The order of planting was two trees of Rome, then four IIs of Stayman; this planting being repeated four times until the was filled. In the spring of 1924 , every other tree was removed icrive the permanent trees more room. This left only one tree of Rne and two trees of Stayman for each method of treatment. An aimpt was made to prune the trees uniformly, this, however, was 1 cult, due to the wide differences in the types of trees and their [() onses. 
The methods of training and subsequent pruning were as follow The trees were trained to the modified central leader form, having th seaffolds of four main branches each. The upper seaffold was appro mately three feet from the lower one. The first season, the lower se fold branches were selected and if they had made more than eighte inches growth they were cut back to that length. 'The central lear was left from twenty to twenty-four inches long. All other brancl were removed. Pruning the second season consisted of reducing number of laterals on each main seaffold branch to two, all ot shoots being removed. The eentral leader was headed back to $a b$ four feet from the first scaffold.

In the third and fourth seasons, the second scaffold was formedi the same manner as the first. The subsequent pruning was light a consisted mostly of a mere thinning out of thick places in the tris and the removal of interfering or crossing limbs. No heading b was practiced after the fourth season. In all cases, it was the aim give all the trees the same type and severity of pruning. This impossible during the first two or three years in the case of the hi headed trees, because of their tendency to produce branches below head. These shoots had to be removed in addition to the prun necessary to train the trees. In this way, the high-headed trees ceived a little heavier pruning than the low-headed ones, for the is few years. Since that time, there has been practically no differenc ir pruning trees of different heights' of heads.

\section{CARE OF THE ORCHARD}

The trees in the experimental plot received cultivation and cie crops each year. The cultivation consisted of five to ten treatm with a light draft harrow, a spike-tooth harrow, or dise, as the na r of the soil warranted. A cover crop consisting of a mixture of and hairy vetch was sowed during August. In the spring, the cres crop was plowed or disced under. An application of about t: hundred pounds of 16 per cent superphosphate (acid phosphate) made at the time of seeding the cover crop. In the spring of 1924, be trees received the only application of nitrogen, which consisted of pounds of nitrate of soda per tree. This was applied when the tee were in bloom. The trees were kept thoroughly sprayed, at all ties to prevent any damage by insect pests or diseases. 


\section{METHODS OF OBTAINING DATA}

In order to determine the exact amount of growth made each ar by the trees of different heights of heads, the total lengths of the w shoots for the previous growing season were measured in the rly spring. The trees were then pruned and the length of the onear-old wood removed was measured. The new growth produced ch year was measured for the first six years, after this, the only 'owth measurement made was the annual increase in trunk diameter.

When the trees in this experiment were planted, the diameters of eir trunks were measured with calipers at a point approximately half ay between the ground and the place where the heads were to be rmed. This point was marked by painting a narrow band half way ound the tree. The tree trunks were measured each year with the ception of 1918 and 1919.

To get a record of the fruiting of the trees, the number of blossom usters was counted, and the yield of fruit was measured in total aight in pounds and in total number of apples produced.

\section{PRESENTATION OF DATA}

In presenting the data in this report, the individual, year-by-year se records are given in two instances, while in all other cases only erages of the trees for each of the various treatments are recorded. calculating the data for the annual length of shoot growth and the erage annual increase in trunk circumference, Student's Method ,5), which has been advocated by Love and Brunson (3) as an aid interpreting similar data, was used. In the tables where this method calculation was used, the column dealing with odds is important, as gives a fairly accurate measure of the significance of the differences wreen treatments. Odds much below 30:1 indicate tendencies only, ile greater odds approach absolute certainty, as a limit.

\section{TREE GROWTH}

The data presented in this report cover the first nine years after trees were set, 1916-1924, inclusive, hence they are largely conned with tree growth up to the age at which fruit production began.

\section{Annual Shoot Growth}

Table 1 shows the average total length of annual shoot growth per e for the first six years. The low-headed trees, with one exception, rde much more growth than those which were headed higher. This 'rue regardless of whether any one year's growth or all of the six 
TABLE 1.-Length of Shoot Growth Produced by Individual Trees the F Six Growing Seasons Following Planting.

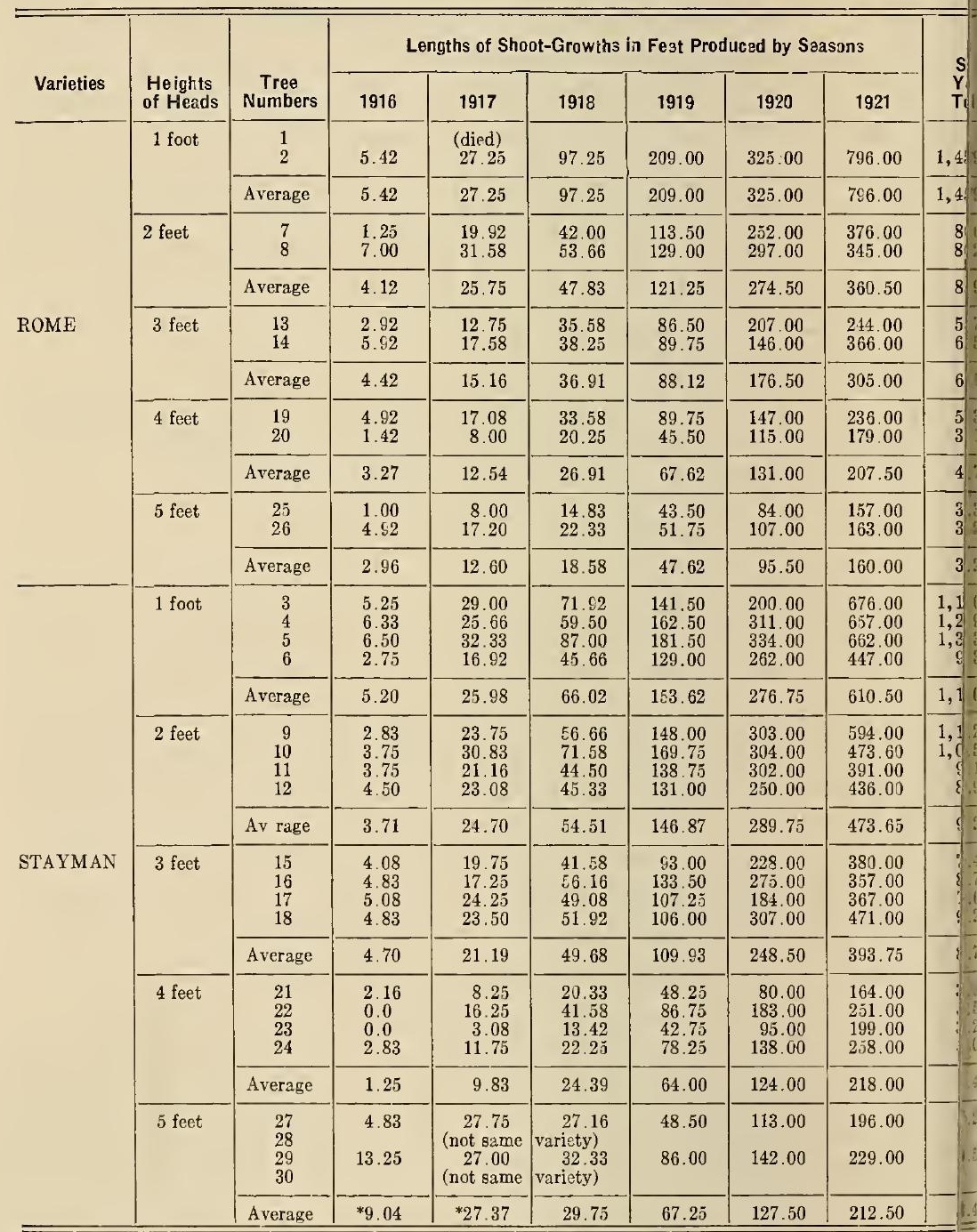

* Most of this growth was produced near the ground and had to be removed. 
'ear's' growths are considered. During the first growing season the rees headed at one foot made more growth than those headed at two eet. but the amount of shoot growth decreased as the height of head nereased. The one exception, as has been noted, was the Stayman rees headed at five feet. These trees made considerably more growth uring the first three years after being set in the orchard than those eaded at four feet. This was due to the fact that the trees headed at re feet produced a large part of their branches below the head, laking it necessary to remove them. This lot of trees was the only we to form any number of branches' below the head.

The Rome trees headed at the same height did not respond in the ame way. During the third growing season the trees of this variety eaded at one foot made about three times as much growth as those eaded at five feet. The same ratio existed at the end of the six-year eriod. As the experiment progressed the difference in growth between he high-headed and the low-headed trees became more pronounced.

Data for total length of annual growth as influenced by the height f head have been calculated, using Student's Method, and are given Table 2.

\section{ABLE 2.-Comparison of Annual Growths as Influenced by Different Heights of Heads.*}

\begin{tabular}{|c|c|c|c|c|c|c|}
\hline \multirow{2}{*}{ Variet es } & \multirow{2}{*}{ Year } & \multicolumn{5}{|c|}{ Comparative Growths at Different Heights of Heads } \\
\hline & & 1 Foot & 2 Feet & 3 Feet & 4 Feet & 5 Feet \\
\hline \multirow{7}{*}{ ROME } & 1916 & 1.00 & .76 & .81 & .60 & .54 \\
\hline & 1917 & 1.00 & .94 & .55 & .46 & .46 \\
\hline & 1918 & 1.00 & .49 & .38 & .27 & .19 \\
\hline & 1919 & 1.00 & .58 & .42 & .32 & .22 \\
\hline & 1920 & 1.00 & .84 & .54 & .40 & .29 \\
\hline & 1921 & 1.00 & .45 & .38 & .26 & .20 \\
\hline & $\begin{array}{l}\text { Average } \\
\text { Odds }\end{array}$ & 1.00 & $\begin{array}{r}.67 \\
800: 1\end{array}$ & $\begin{array}{r}.51 \\
2499: 1\end{array}$ & $\begin{array}{r}.38 \\
9999: 1\end{array}$ & $\begin{array}{r}.31 \\
9999: 1\end{array}$ \\
\hline \multirow{7}{*}{ STAYMAN } & 1916 & 1.00 & .71 & .90 & .24 & 1.74 \\
\hline & 1917 & 1.00 & .95 & .81 & .38 & 1.05 \\
\hline & 1918 & 1.00 & .82 & .75 & .37 & .45 \\
\hline & 1919 & 1.00 & .95 & .71 & .41 & .43 \\
\hline & 1920 & 1.00 & 1.04 & .89 & .44 & .46 \\
\hline & 1921 & 1.00 & .77 & .64 & .35 & .35 \\
\hline & $\begin{array}{l}\text { Average } \\
\text { Odd s }\end{array}$ & 1.00 & $\begin{array}{r}.87 \\
32: 1\end{array}$ & $\begin{array}{r}.78 \\
521: 1\end{array}$ & $\begin{array}{r}.36 \\
9999: 1\end{array}$ & $\begin{array}{l}.74 \\
5: 1\end{array}$ \\
\hline
\end{tabular}

"In this table, the avarage annual length of $n \geq x$ gro.rth prolusal ou t's e trass hasdad at one foot has been taken as

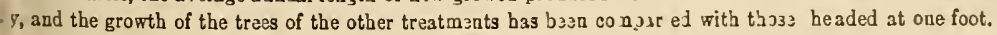


The annual growth of the trees of various heights of head he been compared with those headed at one foot. In every instance ht one, the odds were very significant in favor of the trees headed at foot. This exception was in the case of the Stayman trees headed five feet. As has already been pointed out the variation was due the fact that these trees made most of their growth below the hes the first two years.

\section{Severity of Pruning}

Experiments have shown that pruning has a dwarfing effect young trees. It is also true that the more severe the pruning greater the trees are dwarfed. As the type and amount of prunir necessary to shape and train the trees with different heights of her must vary to some extent, if any difference existed in pruning, effect of the height of head might be overcome. In order to elimin any influence of pruning, the trees were pruned as nearly as possi in the same manner and with the same severity (excepting the prunig necessary to keep branches from the trunks). Careful records wie kept of the total length of one-year-old wood removed each year. Thie data are given in Table 3 .

TABLE 3.-Average and Total Lengths of Wood Removed in Pruning corded by Varieties, Different Heighths of Heads, and Years.

\begin{tabular}{|c|c|c|c|c|c|c|c|}
\hline \multirow{2}{*}{ Varieties } & \multirow{2}{*}{$\begin{array}{l}\text { Hegths } \\
\text { of Heads }\end{array}$} & \multicolumn{5}{|c|}{ Average Length of Wood Removed in Feet per Tree by Years } & \multirow{2}{*}{$\begin{array}{c}\text { Total W' } \\
\text { Remove }\end{array}$} \\
\hline & & 1917 & 1918 & 1919 & 1920 & 1921 & \\
\hline \multirow{5}{*}{ ROME } & 1 foot & 15.2 & 75.6 & 118.5 & 152.0 & 224.0 & 585.3 \\
\hline & 2 feet & 17.3 & 32.2 & 68.5 & 153.5 & 216.0 & 487. \\
\hline & 3 feet & 6.3 & 24.7 & 52.7 & 99.0 & 191.5 & 374 \\
\hline & 4 feet & 8.5 & 19.9 & 36.7 & 71.5 & 127.0 & $263 . \epsilon$ \\
\hline & 5 feet & 10.9 & 13.2 & 23.8 & 56.5 & 90.0 & 194.4 \\
\hline \multirow{5}{*}{ STAYMAN } & 1 foot & 14.6 & 37.6 & 88.4 & 126.0 & 282.3 & 548. \\
\hline & 2 feet & 15.4 & 30.7 & 88.5 & 146.0 & 269.0 & 549. \\
\hline & 3 feet & 14.3 & 30.7 & 68.2 & 124.2 & 213.7 & 451.1 \\
\hline & 4 feet & 5.9 & 16.8 & 32.3 & 56.2 & 102.5 & 213. \\
\hline & 5 feet & 24.1 & 22.6 & 41.2 & 58.0 & 124.0 & 269. \\
\hline
\end{tabular}

From the data in Table 3 and those given in Table 1, the perce ages of each year's growth removed by pruning during the first $f_{3}$ seasons have been calculated and are given in Table 4. 
TABLE 4.-Percentage of Each Year's Growth Removed by Pruning, 1917 1921 Inclusive.

\begin{tabular}{|c|c|c|c|c|c|c|c|}
\hline \multirow{2}{*}{ Var eties } & \multirow{2}{*}{$\begin{array}{l}\text { Heights } \\
\text { of Heads }\end{array}$} & \multicolumn{5}{|c|}{ Percentage of Total Annual Growth Removed by Years } & \multirow{2}{*}{$\begin{array}{c}\text { Percentage of } \\
\text { GrowthRemoved } \\
1917-1921\end{array}$} \\
\hline & & 1917 & 1918 & 1919 & 1920 & 1921 & \\
\hline ROME & $\begin{array}{l}1 \text { foot } \\
2 \text { feet } \\
3 \text { feet } \\
4 \text { feet } \\
5 \text { feet }\end{array}$ & $\begin{array}{l}55.9 \\
67.1 \\
41.5 \\
67.7 \\
86.5\end{array}$ & $\begin{array}{l}77.7 \\
67.3 \\
66.9 \\
73.9 \\
71.0\end{array}$ & $\begin{array}{l}56.6 \\
56.4 \\
59.8 \\
54.2 \\
49.9\end{array}$ & $\begin{array}{l}46.7 \\
55.9 \\
56.0 \\
54.5 \\
59.1\end{array}$ & $\begin{array}{l}28.1 \\
59.9 \\
62.7 \\
61.2 \\
56.2\end{array}$ & $\begin{array}{l}40.09 \\
58.45 \\
59.76 \\
58.74 \\
57.61\end{array}$ \\
\hline STAYMAN & $\begin{array}{l}1 \text { foot } \\
2 \text { feet } \\
3 \text { feet } \\
4 \text { feet } \\
5 \text { feet }\end{array}$ & $\begin{array}{l}56.1 \\
62.3 \\
67.4 \\
60.0 \\
88.1\end{array}$ & $\begin{array}{l}56.9 \\
56.3 \\
61.7 \\
68.8 \\
75.9\end{array}$ & $\begin{array}{l}57.5 \\
60.2 \\
62.0 \\
50.4 \\
61.2\end{array}$ & $\begin{array}{l}45.5 \\
50.3 \\
50.0 \\
45.3 \\
45.4\end{array}$ & $\begin{array}{l}46.2 \\
56.7 \\
54.2 \\
47.0 \\
58.3\end{array}$ & $\begin{array}{l}48.23 \\
55.33 \\
54.49 \\
48.40 \\
57.01\end{array}$ \\
\hline
\end{tabular}

In the case of both varieties, the trees headed at one foot had the least amount of wood removed. The trees which were headed higher than one foot, with one exception, received practically the same severity of pruning. This exception was in the case of Stayman headed at four feet, which had about 7 percent less wood removed than did the other trees headed higher than one foot. The striking thing brought out in this table is that the trees headed at five feet required the removal of but little more wood to form the head at that height than was required for those headed at two feet. The Rome trees headed at two feet had approximately 1 percent more wood removed than those headed at five feet, while the Stayman trees headed at five feet required the removal of about 2 percent more wood than those headed at two feet.

The low-headed trees, in their first and second growing seasons, produced fewer and longer shoots than the high-headed trees. During the succeeding years, the growth produced on the main scaffold branches and primary laterals was distributed so much better on the low-headed trees that more wood could be left to advantage. The differences in the amounts of wood removed in pruning the trees of different heights of heads, however, would not account for the great differences obtained in shoot growth.

\section{Weight of Wood Removed by Pruning}

During the four-year period, 1922-1925 inclusive, the wood removed by pruning was weighed. These data are given in Table 5 . 
TABLE 5.-Average and Total Weights of Wood Removed in Pruning, Rt corded by Varieties, Different Heights of Heads, and Years.

\begin{tabular}{|c|c|c|c|c|c|c|c|}
\hline \multirow{2}{*}{ Varietles } & \multirow{2}{*}{$\begin{array}{l}\text { Heights } \\
\text { of Heads }\end{array}$} & \multicolumn{4}{|c|}{$\begin{array}{l}\text { Average Weight of Wood Removed per Tree } \\
\text { by Years in Pounds }\end{array}$} & \multirow{2}{*}{$\begin{array}{l}\text { Total for } \\
\text { Four Years }\end{array}$} & \multirow{2}{*}{$\begin{array}{l}\text { Average } \\
\text { per Year }\end{array}$} \\
\hline & & 1922 & 1923 & 1924 & 1925 & & \\
\hline ROME & $\begin{array}{l}1 \text { foot } \\
2 \text { feet } \\
3 \text { feet } \\
4 \text { feet } \\
5 \text { feet }\end{array}$ & $\begin{array}{l}9.50 \\
3.75 \\
2.12 \\
1.50 \\
1.37\end{array}$ & $\begin{array}{r}12.20 \\
3.95 \\
2.85 \\
1.80 \\
2.40\end{array}$ & $\begin{array}{r}12.40 \\
4.70 \\
3.25 \\
3.50 \\
2.65\end{array}$ & $\begin{array}{r}17.30 \\
4.00 \\
3.00 \\
2.10 \\
1.60\end{array}$ & $\begin{array}{r}51.40 \\
16.40 \\
11.22 \\
8.90 \\
8.02\end{array}$ & $\begin{array}{r}12.85 \\
4.10 \\
2.80 \\
2.22 \\
2.00\end{array}$ \\
\hline STAYMAN & $\begin{array}{l}1 \text { foot } \\
2 \text { feet } \\
3 \text { feet } \\
4 \text { feet } \\
5 \text { feet }\end{array}$ & $\begin{array}{l}6.37 \\
6.50 \\
4.62 \\
2.18 \\
2.25\end{array}$ & $\begin{array}{l}7.35 \\
7.00 \\
7.15 \\
2.17 \\
3.55\end{array}$ & $\begin{array}{l}7.76 \\
7.12 \\
7.05 \\
3.77 \\
3.65\end{array}$ & $\begin{array}{r}9.80 \\
10.70 \\
10.20 \\
4.45 \\
\ldots .\end{array}$ & $\begin{array}{c}31.28 \\
31.32 \\
29.02 \\
12.57 \\
\ldots\end{array}$ & $\begin{array}{l}7.82 \\
7.83 \\
7.25 \\
3.14 \\
\ldots .\end{array}$ \\
\hline
\end{tabular}

*All pruning was done during the spring months each year.

The data presented in Table 5 show that the amount of wood re moved was closely proportional to the growth the trees made durin the first six growing seasons. The Stayman trees may be divided int two classes as to the severity of the pruning, those headed from one $t$ three feet, and those from four to five feet. The trees headed at thre feet were smaller at the time of this report (May, 1926) than thos headed at two feet or one foot. Yet, for some unaccountable reason the difference in pruning during the four-year period (1922-25) wa not in proportion to tree size, as these higher headed trees were pruner almost as heavily as those headed lower.

The Rome trees headed at one foot had, due to their much large: size, much more wood removed from them than any of the others These trees were probably better located than any of the others or account of a slight dip in the land, which caused the soil to have : higher moisture content and possibly greater fertility. These differ ences in pruning and in the soil were not sufficient, however, to in fluence greatly the growth or size of trees, as was shown by trees of the same varieties which grew in an adjacent row, sixteen feet away and received the same culture.

\section{Increase in Circumference of Tree Trunks}

The annual increases in the circumference of the tree trunks were measured from the time the trees were planted. These data are given in Table 6 .

The trunks of the higl-headed trees were much smaller in circumference than those of the low-headed trees. The circumference of the 
TABLE 6.-Comparison of Circumferences of Tree Trunks by Varieties, Heights of Heads, and Years.

\begin{tabular}{|c|c|c|c|c|c|c|c|c|c|}
\hline \multirow[b]{2}{*}{ Varieties } & \multirow{2}{*}{$\begin{array}{c}\text { Heights } \\
\text { of Heads }\end{array}$} & \multirow{2}{*}{$\begin{array}{c}\text { Tree } \\
\text { Numbers }\end{array}$} & \multirow{2}{*}{$\begin{array}{c}\text { Circum- } \\
\text { ferences at } \\
\text { Planting } \\
\text { in } 1916\end{array}$} & \multicolumn{6}{|c|}{ Circumferences of Tree Trunks in Inches by Years* } \\
\hline & & & & 1916 & 1919 & 1920 & 1921 & 1922 & 1923 \\
\hline \multirow{10}{*}{ ROME } & 1 foot & $\begin{array}{l}1 \\
2 \\
\end{array}$ & 1.13 & $\begin{array}{c}\text { (died) } \\
1.26\end{array}$ & 5.87 & 8.50 & 11.25 & 14.00 & 16.12 \\
\hline & & Average & 1.1 & 1.26 & 5.87 & 8.50 & 11.25 & 14.00 & 16. 12 \\
\hline & \multirow[t]{2}{*}{2 feet } & $\begin{array}{l}7 \\
8 \\
\end{array}$ & $\begin{array}{l}1.19 \\
1.26\end{array}$ & $\begin{array}{l}1.29 \\
1.63\end{array}$ & $\begin{array}{l}4.50 \\
4.62\end{array}$ & $\begin{array}{l}6.25 \\
6.25\end{array}$ & $\begin{array}{l}8.37 \\
8.00\end{array}$ & $\begin{array}{r}10.12 \\
9.50\end{array}$ & $\begin{array}{l}11.75 \\
10.75\end{array}$ \\
\hline & & Average & 1.22 & 1.46 & 4.56 & 6.25 & 8.18 & 9.81 & 11.25 \\
\hline & \multirow[t]{2}{*}{3 feet } & $\begin{array}{l}13 \\
14 \\
\end{array}$ & $\begin{array}{r}.91 \\
.85 \\
\end{array}$ & $\begin{array}{r}.97 \\
1.04 \\
\end{array}$ & $\begin{array}{l}3.37 \\
3.87 \\
\end{array}$ & $\begin{array}{l}4.87 \\
5.37 \\
\end{array}$ & $\begin{array}{l}6.25 \\
7.00 \\
\end{array}$ & $\begin{array}{l}7.75 \\
8.75 \\
\end{array}$ & $\begin{array}{r}9.50 \\
10.25 \\
\end{array}$ \\
\hline & & Average & .88 & 1.00 & 3.62 & 5.12 & 6.62 & 8.25 & 9.87 \\
\hline & \multirow[t]{2}{*}{4 feet } & $\begin{array}{l}19 \\
20\end{array}$ & $\begin{array}{r}1.00 \\
.85\end{array}$ & $\begin{array}{l}1.10 \\
1.04\end{array}$ & $\begin{array}{l}3.87 \\
3.00\end{array}$ & $\begin{array}{l}5.50 \\
4.50\end{array}$ & $\begin{array}{l}7.12 \\
5.75\end{array}$ & $\begin{array}{l}8.50 \\
7.00\end{array}$ & $\begin{array}{r}10.25 \\
8.50\end{array}$ \\
\hline & & Average & .92 & 1.07 & 3.43 & 5.00 & 6.43 & 7.75 & 9.37 \\
\hline & \multirow[t]{2}{*}{5 feet } & $\begin{array}{l}25 \\
26 \\
\end{array}$ & $\begin{array}{r}.88 \\
1.13 \\
\end{array}$ & $\begin{array}{l}1.13 \\
1.41 \\
\end{array}$ & $\begin{array}{r}3.25 \\
3.50 \\
\end{array}$ & $\begin{array}{l}4.02 \\
4.87 \\
\end{array}$ & $\begin{array}{l}6.37 \\
6.37 \\
\end{array}$ & $\begin{array}{l}7.62 \\
7.75 \\
\end{array}$ & $\begin{array}{l}9.50 \\
9.25 \\
\end{array}$ \\
\hline & & Average & 1.00 & 1.27 & 3.37 & 4.74 & 6.37 & 7.68 & 9.37 \\
\hline \multirow{10}{*}{ MAN } & \multirow[t]{2}{*}{1 foot } & $\begin{array}{l}3 \\
4 \\
5 \\
6 \\
\end{array}$ & $\begin{array}{l}1.57 \\
1.63 \\
1.50 \\
1.44 \\
\end{array}$ & $\begin{array}{l}2.01 \\
1.82 \\
2.01 \\
1.63 \\
\end{array}$ & $\begin{array}{l}6.62 \\
6.62 \\
6.62 \\
5.50 \\
\end{array}$ & $\begin{array}{l}9.00 \\
8.87 \\
9.12 \\
7.87 \\
\end{array}$ & $\begin{array}{r}11.62 \\
11.25 \\
10.62 \\
9.75 \\
\end{array}$ & $\begin{array}{l}13.75 \\
13.25 \\
13.50 \\
11.50\end{array}$ & $\begin{array}{l}15.75 \\
15.75 \\
13.25\end{array}$ \\
\hline & & Average & 1.53 & 1.87 & 6.34 & 8.71 & 10.81 & 13.00 & 14.92 \\
\hline & \multirow[t]{2}{*}{2 feet } & $\begin{array}{r}9 \\
10 \\
11 \\
12 \\
\end{array}$ & $\begin{array}{l}1.50 \\
1.60 \\
1.50 \\
1.32 \\
\end{array}$ & $\begin{array}{l}1.63 \\
1.92 \\
1.63 \\
1.41 \\
\end{array}$ & $\begin{array}{l}6.00 \\
6.50 \\
5.50 \\
5.75 \\
\end{array}$ & $\begin{array}{l}8.25 \\
9.00 \\
7.50 \\
8.00 \\
\end{array}$ & $\begin{array}{r}10.87 \\
11.37 \\
19.50 \\
10.12 \\
\end{array}$ & $\begin{array}{l}12.75 \\
13.25 \\
11.12 \\
12.12 \\
\end{array}$ & $\begin{array}{l}15.00 \\
15.50 \\
13.00 \\
14.50 \\
\end{array}$ \\
\hline & & Average & 1.48 & 1.64 & 5.93 & 8.18 & 10.46 & 12.31 & $14 . \overline{5} 0$ \\
\hline & \multirow[t]{2}{*}{3 feet } & $\begin{array}{l}15 \\
16 \\
17 \\
18 \\
\end{array}$ & $\begin{array}{l}1.32 \\
1.32 \\
1.16 \\
1.19 \\
\end{array}$ & $\begin{array}{l}1.57 \\
1.44 \\
1.29 \\
1.29 \\
\end{array}$ & $\begin{array}{l}5.25 \\
5.62 \\
4.50 \\
5.50 \\
\end{array}$ & $\begin{array}{l}7.25 \\
7.75 \\
6.25 \\
7.50 \\
\end{array}$ & $\begin{array}{r}9.62 \\
10.12 \\
8.00 \\
9.62 \\
\end{array}$ & $\begin{array}{r}11.50 \\
12.00 \\
9.25 \\
11.50 \\
\end{array}$ & $\begin{array}{l}14.00 \\
14.37 \\
11.00 \\
13.75\end{array}$ \\
\hline & & Average & 1.24 & 1.39 & 5.21 & 7.18 & 9.31 & 11.06 & 13.28 \\
\hline & \multirow[t]{2}{*}{4 feet } & $\begin{array}{l}21 \\
22 \\
23 \\
24 \\
\end{array}$ & $\begin{array}{l}1.19 \\
1.16 \\
1.16 \\
1.32 \\
\end{array}$ & $\begin{array}{l}1.26 \\
1.26 \\
1.19 \\
1.3 j \\
\end{array}$ & $\begin{array}{l}3.75 \\
5.00 \\
3.25 \\
4.50 \\
\end{array}$ & $\begin{array}{l}5.25 \\
7.37 \\
5.12 \\
6.25 \\
\end{array}$ & $\begin{array}{l}6.62 \\
9.62 \\
6.75 \\
7.87 \\
\end{array}$ & $\begin{array}{r}8.00 \\
11.37 \\
8.50 \\
9.25 \\
\end{array}$ & $\begin{array}{r}9.75 \\
13.50 \\
10.5 \\
11.00 \\
\end{array}$ \\
\hline & & Average & 1.20 & 1.26 & 4.12 & 5.99 & 7.71 & 9.28 & 11.18 \\
\hline & \multirow[t]{2}{*}{5 feet } & $\begin{array}{l}27 \\
28 \\
29 \\
30 \\
\end{array}$ & $\begin{array}{l}1.07 \\
1.09\end{array}$ & $\begin{array}{c}1.38 \\
\text { (not same } \\
1.35 \\
\text { (not same } \\
\end{array}$ & $\begin{array}{r}3.50 \\
\text { variety) } \\
4.12 \\
\text { variety) } \\
\end{array}$ & $\begin{array}{l}5.12 \\
5.62\end{array}$ & $\begin{array}{l}7.25 \\
7.25\end{array}$ & $\begin{array}{l}9.00 \\
8.50\end{array}$ & $\begin{array}{l}11.25 \\
10.12\end{array}$ \\
\hline & & Average & 1.08 & 1.36 & 3.81 & 5.37 & 7.25 & 8.75 & 10.68 \\
\hline
\end{tabular}

1 measurements were taken at the end of the growing season each year. 


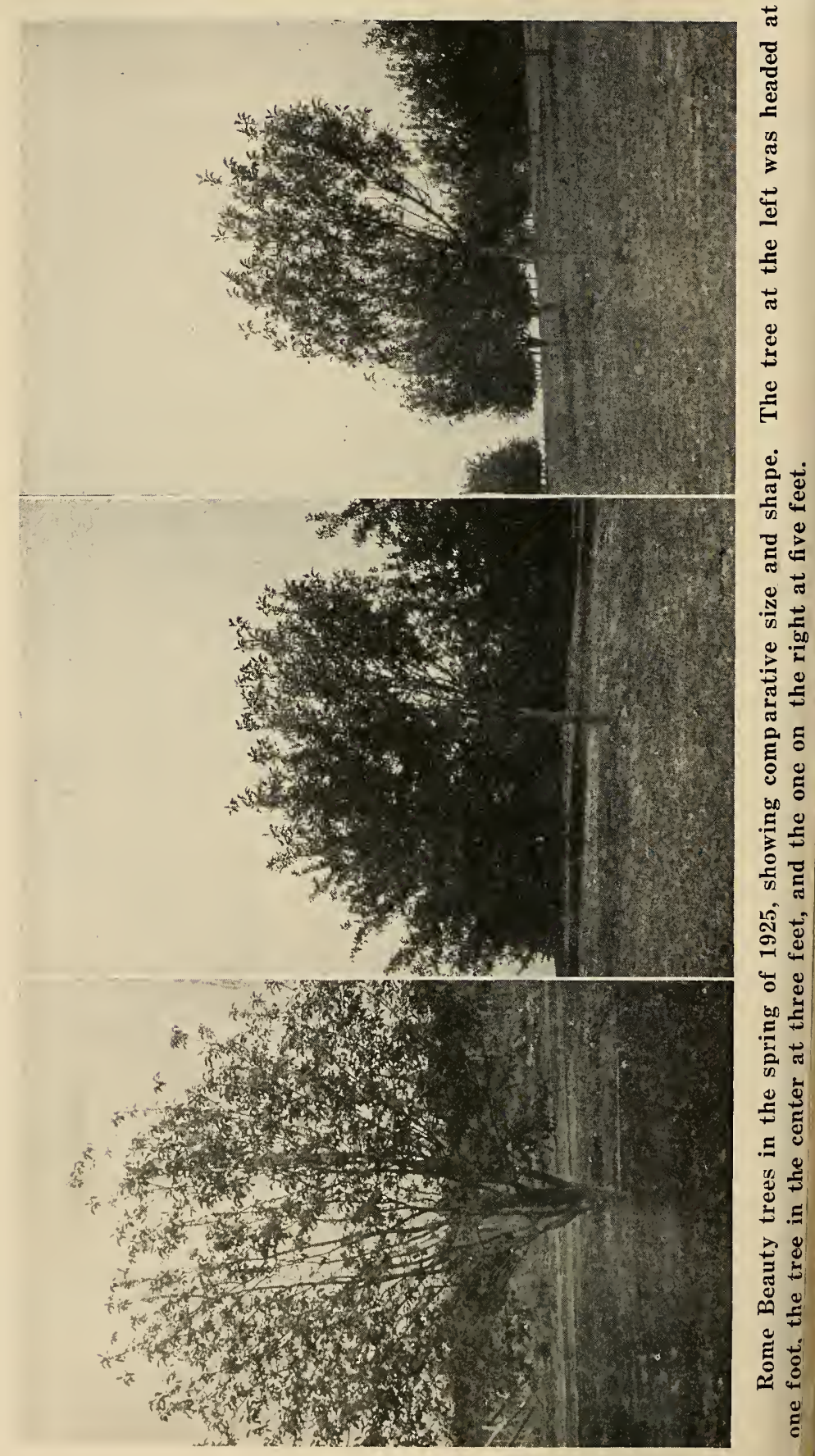


ree trunks became smaller as the height of the head increased. From able 6, it may be seen that the Stayman made larger gains in trunk ircumference than the Rome, due to the more vigorous growth of his variety.

In Table 7 is given the average yearly increase in trunk circumerence as influenced by the height of head of the trees. The total nerease in the circumference of the trunk was greatest, on both arieties with the trees headed at one foot. The increase in trunk irth became less as the height of the head increased. When the ifferences between the trees headed at one foot and those headed igher were compared by Student's method, it was found that, in the ise of the Rome, all the trees headed higher than one foot had made gnificantly smaller increases in trunk circumference than those eaded at one foot. With the Stayman, however, significant odds ere found only with those trees headed at four feet.

ABLE 7.-Average Increases in Trunk Circumferences Recorded by Varieties, Different Heights of Heads, and Years.

\begin{tabular}{|c|c|c|c|c|c|c|c|c|c|c|}
\hline \multirow{2}{*}{ |arieties } & \multirow{2}{*}{$\begin{array}{l}\text { Heights } \\
\text { of Heads }\end{array}$} & \multicolumn{6}{|c|}{$\begin{array}{l}\text { Average Increases in Trunk Circumferences in } \\
\text { Inches Recorded by Growing Seasons }\end{array}$} & \multirow{2}{*}{$\begin{array}{c}\text { Total } \\
\text { Increase } \\
\text { for Eight } \\
\text { Seasons }\end{array}$} & \multirow{2}{*}{$\begin{array}{c}\text { Average } \\
\text { Increase } \\
\text { per Season }\end{array}$} & \multirow{2}{*}{$\begin{array}{c}\text { Odds In } \\
\text { Favor of } \\
\text { 1-Foot } \\
\text { Head }\end{array}$} \\
\hline & & 1916 & ${ }^{*} 1919$ & 1920 & 1921 & 1922 & 1923 & & & \\
\hline \multirow{5}{*}{ ME } & 1 foot & .13 & 4.61 & 2.63 & 2.75 & 2.75 & 2.12 & 14.99 & 2.50 & \\
\hline & 2 feet & .24 & 3.10 & 1.69 & 2.13 & 1.63 & 1.44 & 10.23 & 1.70 & $118: 1$ \\
\hline & 3 feet & .12 & 2.62 & 1.50 & 1.50 & 1.63 & 1.52 & 8.89 & 1.48 & $132: 1$ \\
\hline & 4 feet & .15 & 2.36 & 1.57 & 1.43 & 1.32 & 1.52 & 8.35 & 1.39 & $112: 1$ \\
\hline & 5 feet & .27 & 1.10 & 1.37 & 1.63 & 1.01 & 1.69 & 7.07 & 1.17 & $38: 1$ \\
\hline \multirow{5}{*}{ IYMAN } & 1 foot & .34 & 4.47 & 2.37 & 2.10 & 2.19 & 1.92 & 13.39 & 2.23 & \\
\hline & 2 feet & .16 & 4.29 & 2.25 & 2.28 & 1.85 & 2.19 & 13.02 & 2.17 & $3: 1$ \\
\hline & 3 feet & .15 & 3.82 & 1.97 & 2.16 & 1.72 & 2.22 & 12.04 & 2.00 & 11:1 \\
\hline & 4 feet & .06 & 2.86 & 1.87 & 1.72 & 1.57 & 1.90 & 9.98 & 1.66 & $38: 1$ \\
\hline & 5 feet & .28 & 2.45 & 1.56 & 1.88 & 1.50 & 1.93 & 9.60 & 1.60 & $19: 1$ \\
\hline
\end{tabular}

Includes growth for seasons of 1917 and 1918.

\section{Volume of Top}

In an attempt to show more clearly the differences existing in tree :e and bearing surface, the height and spread of the trees were sasured in the early spring of 1925. The distance from the ground the lowest limbs was also measured. The tops of the trees were und to conform more closely to the shape of a sphere than to any 'uer geometrical figure, as the trees had not borne crops sufficiently ary to spread the tops. To calculate the volume of the tree tops, of which may be considered potential bearing area, the distance fom the ground to the lowest limbs was subtracted from the height 
of the trees, which gave the diameter of the top in a vertical directio This was then averaged with the width of the tree, which resulted what was used as the diameter of the tree or sphere. The volume the sphere was then calculated in the usual manner $(\mathrm{V}=1 / 6 \pi \mathrm{D}$ These data are given in Table 8.

TABLE 8.-Heights, Widths, and Volumes of Trees as Influenced by Heigh of Heads; Measurements Made in the Spring of 1925.

\begin{tabular}{|c|c|c|c|c|c|}
\hline Varieties & $\begin{array}{l}\text { Heights } \\
\text { of Heads }\end{array}$ & $\begin{array}{l}\text { Average } \\
\text { Heights } \\
\text { in Feet }\end{array}$ & $\begin{array}{l}\text { Average } \\
\text { Widtins } \\
\text { in Feot }\end{array}$ & $\begin{array}{l}\text { Average Distances } \\
\text { from Ground to } \\
\text { Limbs in f"eet }\end{array}$ & $\begin{array}{c}\text { Average Volumes } \\
\text { Tops in Cubic } \\
\text { Feet }\end{array}$ \\
\hline ROME & $\begin{array}{l}1 \text { foot } \\
2 \text { feat } \\
3 \text { feet } \\
4 \text { faet } \\
5 \text { feat }\end{array}$ & $\begin{array}{l}15.0 \\
12.5 \\
12.5 \\
13.0 \\
13.5\end{array}$ & $\begin{array}{r}16.0 \\
11.0 \\
9.5 \\
8.0 \\
8.0\end{array}$ & $\begin{array}{l}2.50 \\
3.25 \\
4.00 \\
4.75 \\
5.50\end{array}$ & $\begin{array}{r}1515.08 \\
543.45 \\
381.70 \\
280.31 \\
268.08\end{array}$ \\
\hline STAYMAN & $\begin{array}{l}1 \text { foot } \\
2 \text { feet } \\
3 \text { feet } \\
4 \text { feet } \\
5 \text { feet }\end{array}$ & $\begin{array}{l}15.50 \\
15.75 \\
15.62 \\
15.25\end{array}$ & $\begin{array}{c}16.75 \\
17.03 \\
17.09 \\
14.50 \\
\text { es remov }\end{array}$ & $\begin{array}{r}1.25 \\
2.00 \\
3.12 \\
4.25 \\
\text { his tim } 3 \text { ) }\end{array}$ & $\begin{array}{l}1949.81 \\
1901.11 \\
1680.23 \\
1085.23\end{array}$ \\
\hline
\end{tabular}

The high-headed trees were several years behind the low-head trees in actual size when the top measurements were taken in $19 \%$ They were less stocky, less vigorous, and much lesis desirable. T lower the trees had been headed, the larger was the top, as shown 1 measurements of height and breadth, or total volume. Both varieti responded in the same way. The Stayman, being a more vigoro grower, made larger trees than the Rome, but the response to $t$ height of head was the same.

\section{BLOOIM AND YIELD}

As has been stated, since this report covers only the first ni years of the life of the trees after they were set in the orchard, it mi necessarily deal largely with growth. The trees were still so you at the time this report was prepared that very little could be expect from them in bloom and yield of fruit.

The trees produced their first bloom in the spring of 1920, fo years after they were set in the orchard. At this time, the number blossom clusters was counted on each tree. This' was continued $f$ three more years. These data are given in Table 9 .

It is interesting to note that the high-headed trees were the first bloom, and that they continued to bloom more heavily than the lo headed trees. This is especially significant when the great differen in size of the trees is considered. 
CABLE 9.-Average Number of Flower Clusters Per Tree Recorded by Varieties, Different Heights of Heads, and Years.

\begin{tabular}{|c|c|c|c|c|c|c|}
\hline \multirow{2}{*}{ Varieties } & \multirow{2}{*}{$\begin{array}{l}\text { Heights } \\
\text { of Heads }\end{array}$} & \multicolumn{4}{|c|}{ Average Number of Flower Clusters per Tree by Years } & \multirow{2}{*}{$\begin{array}{c}\text { Total } \\
1920-23\end{array}$} \\
\hline & & 1920 & 1921 & 1922 & 1923 & \\
\hline ROME & $\begin{array}{l}1 \text { foot } \\
2 \text { feet } \\
3 \text { feet } \\
1 \text { feet } \\
5 \text { feet }\end{array}$ & $\begin{array}{l}0 \\
0 \\
0 \\
3.0 \\
3.5\end{array}$ & $\begin{array}{r}6.5 \\
0.5 \\
2.0 \\
2.0 \\
12.0\end{array}$ & $\begin{array}{r}74.0 \\
.5 \\
13.5 \\
1.5 \\
14.5\end{array}$ & $\begin{array}{r}105.0 \\
32.5 \\
15.7 \\
20.0 \\
164.0\end{array}$ & $\begin{array}{r}185.5 \\
33.5 \\
31.2 \\
26.5 \\
194.0\end{array}$ \\
\hline STAYMAK & $\begin{array}{l}1 \text { foot } \\
2 \text { feet } \\
3 \text { feet } \\
4 \text { feet } \\
5 \text { feet }\end{array}$ & $\begin{array}{l}0 \\
0 \\
0 \\
0 \\
9.0\end{array}$ & $\begin{array}{l}0 \\
0.2 \\
0 \\
0 \\
8.3\end{array}$ & $\begin{array}{r}.3 \\
.5 \\
.5 \\
.54 .5\end{array}$ & $\begin{array}{r}20.0 \\
3.4 \\
12.5 \\
62.5 \\
330.0\end{array}$ & $\begin{array}{r}20.3 \\
3.6 \\
130 \\
62.7 \\
481.8\end{array}$ \\
\hline
\end{tabular}

The only data obtained on rield of fruit were taken for the two rops borne in 1923 and 1924, for which the total weight of fruit was etermined as well as the number of individual fruits produced per 'ee. These data are given in Table 10.

ABLE 10.-Yield in Pounds and Number of Apples ner Tree Recorded by Varieties, Different Heights of Heads, and Years.

\begin{tabular}{|c|c|c|c|c|c|c|c|c|}
\hline \multirow{2}{*}{ Jarieties } & \multirow{2}{*}{$\begin{array}{l}\text { Heights } \\
\text { of Heads }\end{array}$} & \multicolumn{3}{|c|}{$\begin{array}{c}\text { Average Yield in Pounds } \\
\text { per Tree by Years }\end{array}$} & \multicolumn{3}{|c|}{$\begin{array}{c}\text { Average Number of Apples } \\
\text { per Tree by Years }\end{array}$} & \multirow{2}{*}{$\begin{array}{c}\text { Average Weights } \\
\text { of Fruits in } \\
\text { Pounds }\end{array}$} \\
\hline & & 1923 & 1924 & Total & 1923 & 1924 & Total & \\
\hline OME & $\begin{array}{l}1 \text { foot } \\
2 \text { feet } \\
3 \text { feet } \\
4 \text { feet } \\
5 \text { feet }\end{array}$ & $\begin{array}{l}6.0 \\
2.2 \\
5.6 \\
0 \\
6.0\end{array}$ & $\begin{array}{l}9.6 \\
0 \\
2.5 \\
1.5 \\
11.7\end{array}$ & $\begin{array}{r}15.6 \\
2.2 \\
8.1 \\
1.5 \\
17.7\end{array}$ & $\begin{array}{c}19.0 \\
4.0 \\
15.5 \\
0 \\
12.5\end{array}$ & $\begin{array}{c}29.0 \\
0 \\
4.0 \\
3.0 \\
24.0\end{array}$ & $\begin{array}{r}48.0 \\
4.0 \\
19.5 \\
3.0 \\
36.5\end{array}$ & $\begin{array}{l}.32 \\
.55 \\
.41 \\
.50 \\
.48\end{array}$ \\
\hline IAYMAN & $\begin{array}{l}1 \text { foot } \\
2 \text { feet } \\
3 \text { feet } \\
4 \text { feet } \\
5 \text { feet }\end{array}$ & $\begin{array}{r}2.4 \\
.9 \\
1.1 \\
5.3 \\
16.8\end{array}$ & $\begin{array}{r}3.7 \\
18.7 \\
14.3 \\
27.4\end{array}$ & $\begin{array}{r}6.1 \\
19.6 \\
15.4 \\
32.7\end{array}$ & $\begin{array}{r}5.5 \\
2.0 \\
3.7 \\
11.0 \\
62.0\end{array}$ & $\begin{array}{r}9.0 \\
53.5 \\
34.0 \\
65.5\end{array}$ & $\begin{array}{l}14.5 \\
55.5 \\
37.7 \\
76.5\end{array}$ & $\begin{array}{l}.42 \\
.35 \\
.40 \\
.42\end{array}$ \\
\hline
\end{tabular}

The amount of fruit borne to the date of this report was too small be of much value in determining the effect of height of head on fruit oduction. At the end of the first nine-year period, the yield had not en influenced to any appreciable extent by the height of the head. actically all of the effect of the low heading of trees was that of oducing trees of greater size and bearing area. Time alone will tell lether the trees of greater bearing area will produce crops signifintly greater than those of the high-headed trees. 


\section{DISCUSSION}

It is unfortunate that a larger number of trees was not included $j$ this experiment. The data in regard to growth are so consistent, hov ever, that it would seem that the effect of the height of head on th growth and yielding capacity of the trees is fairly clearly define This is especially true when it is considered that the results of th experiment substantiate those secured by Wiggans (6), and Ilowe (2 and the observations of Chandler (1).

Wiggans (6), in reporting on the growth made by similar tre which had been headed at different heights, says that, from the ver beginning, the low-headed trees produced shoots which were mur longer, and at the same time formed a larger number of branches the did the high-headed trees. Although no counts or measurements we made in the West Virginia experiment, it was observed that the lo headed trees produced more shoots, and also longer and stocki shoots', than the trees headed higher. This was especially true as t? trees became older, since the trees headed at five feet grew in a mann similar to trees several years older; that is, the length of growth ar the comparative diameter of the shoots were reduced.

Howe (2) used nine different varieties in testing the effect of his and low heads on growth and fruit production. He reported that, the end of the first ten-year period, the low-headed trees were consi erably larger in actual size, and more vigorous and stocky than $t$ high-headed trees, and further that the low-headed trees of ea variety bloomed and set fruit about one year earlier than the hig headed trees. Every variety but one yielded more fruit when the tre were headed low. He states that "the results indicate an economic advantage in the practice of low-heading due to increased yields a: greater ease in orchard operations, and advances the opinion th unless considerable care is taken in the formation of high heads, $t$ larger amount of wood that must be removed may impair the vigor the trees and check their development.

Under the conditions of the West Virginia experiments this op ion could hardly be true, as there was very little difference in percentages of the total growth removed from the high- and the 10 headed trees. Certainly the great difference in size of trees cannot explained entirely on the basis of the dwarfing effect of prunis There are apparently several factors operating, which taken togetl cause the wide variation in tree size.

Chandler (1) thinks that the large amount of pruning necesses to obtain a high head, and the injury which the young high-heacd 
ees suffer from bending about during early summer are responsible $r$ the rather marked differences in the trees.

Numerous investigations in pruning have shown that the pruning young trees dwarfs them to a degree dependent on the severity of e pruning. In this experiment, it was not necessary to prune the gh-headed trees much more severely than the low-headed ones to rm a high head. Certainly, the small difference between the amount wood removed from the high-and the low-headed trees is too small account for the differences existing in the size of the trees. It should pointed out again that the trees in this experiment were planted as le-year old whips and were headed at the desired height at the time planting. In this way, the main scaffold branches were produced the height desired with a minimum amount of pruning. Had all the ees been headed at the same height at the time they were planted, id the high heads formed later by removing the lower limbs, more vere pruning would have been necessary. This, in view of the esent knowledge of the dwarfing effects of pruning, would probably re caused wider differences in the size of the trees than actually sulted.

As an advantage of low-heading, it is claimed by some investigars that trees so headed do not grow as tall as if they had been headed gher. This claim is not borne out by the results of this experiment, ice only a part of the bearing surface of the low-headed trees was irer than that of the trees headed higher. Considering the actual ight of the trees, the low-headed ones grew as tall as those headed ghest. The striking fact brought out by the data is the uniformity the height of the trees regardless of the height of head. The great$t$ difference in the trees with different heights of heads was in the eadth and not in the actual height of the top. The low-headed trees, rticularly of the Rome variety, developed much wider tops than ose headed higher (See Table 8).

The height of head had no influence on the general type of tree as ch variety maintained its usual characteristics. The high-headed pes had a tendency to bend and lean due to the influence of the preiling winds. This was not so noticeable with the low-headed trees.

In so far as cultivation is concerned, no difference between the rh- and the low-headed trees was found, other than that usually perienced with larger trees. The implements used in cultivation re those commonly employed in the average orchard. Other operons such as pruning and spraying were facilitated by the low-headed es, and, no doubt, when the trees begin to bear heary erops, harvest; operations will be easier. 


\section{CONCLUSIONS}

From the data presented it must be concluded that low-heacd trees make more shoot growth, and larger gain in trunk diamets than high-headed trees. Low-headed trees, as a result of this grear growth, have a larger bearing area than the high-headed trees. the end of nine years, there was no appreciable difference in yield the trees of different heights of heads. The trees were still too you however, to expect much in fruit production. Judging by top ar it would appear that the low-headed trees will likely outyield high-headed trees in the near future.

\section{RECOMMENDATIONS TO GROWERS}

There are considerable variations in the recommendations of $h$ ticulturists, and in the practices of commercial fruit growers, in reged to the height of heading young apple trees. Several important factis are considered in these recommendations and practices, such as eie of spraying, picking, pruning, thinning, prevention of winter inju to the tree trunk, and soil temperature.

The height at which the trees are headed should be determin in a large measure, by the importance that the grower places on $c^{3}$ or more of the foregoing factors. After all, over emphasis may placed on some factor because of the grower's likes or dislikes.

If there is any difference, in tree growth and capacity to bear lar crops, between high- and low-headed trees, the height of head whil produces the largest tree in the shortest time should be given first ec sideration. It should be the aim and desire of the commercial grow to produce a tree as large as possible, which is capable of beari maximum quantities of high grade fruit, in the least time. It believed by the writer that this may be best accomplished by headi the trees low, preferably from one foot to two feet from the bud graft. 


\section{REFERENCES CITED}

(1) Chandler, W. H. 1925. FRUIT GROWING. pp. 282-283. New York.

2) Howe, G. H. 1923. GROWTH AND YLELD OF APPLE TREES PRUNED IN VARIDUS WAYS N. Y. Agr. Exp. Sta. Bul. 500:16-22.

3) Love, H. H., ANd Brunson, A. M.

1924. STUDENT'S METHOD FOR INTERPRETING PAIRED EXPERIMENTS. Amer. Soc. Agron. Jour. 16:60-68.

4) STUDENT.

1908. THE PROBABLE ERROR OF A MEAN. Biometrika 6:1-25.

5)

1917. TABLES FOR ESTIMATING THE PROBABILITY THAT THE MEAN OF UNIQUE SAMPLE OF OBSERVATION LIES BETWEEN—OO AND ANY GIVEN DISTANCE OF THE MEAN OF THE POPULATION FROM WHICH THE SAMPLE IS DRAWN. Biometrika 11:414-417.

5) WIGGANS, C. C.

1918. SOME FACTORS FAVORING OR OPPOSING FRUITFULNESS IN APPLE. Mo. Agr. Exp. Sta. Res. Bul. 32:49-50. 



\section{HECKMAN}

BINDERY INC.

\section{JUNE 99}


